\title{
Los Jaivas: Toward A Decolonial Attitude in Chilean Psychedelic Rock
}

\author{
Israel Holas Allimant \\ Deakin University \\ israel.holas@deakin.edu.au
}

\section{Sergio Holas}

The University of Adelaide

Sergio.holas@adelaide.edu.au

\begin{abstract}
This article proposes a decolonial reading of the rock music produced by Los Jaivas in Chile during the late sixties and early seventies by putting it in dialogue with Rodolfo Kusch's work on identity and Walter Mignolo's notion of decolonial aesthesis. By highlighting Indigenous melodies, rhythms, ideas and experiences in the rock genre, Los Jaivas propose an alternative conception of the Chilean subject as Andean and not exclusively displaced-European, as maintained by Chile's institutions and mainstream culture. The music produced by Los Jaivas articulates a decolonial attitude. It recognises Indigenous values as an integral part of Chilean reality, adding a deeper dimension to the political critique of capitalism that occurred during the Unidad Popular period (1970-1973). Through the enduring music of their first albums and singles, Los Jaivas create an instance of decolonial aesthesis that has profoundly altered Chilean discourses of national identity.
\end{abstract}

KEYWORDS: Chilean rock, decolonial aesthesis, Rodolfo Kusch, Walter Mignolo

\section{Introduction}

In the late 1960s and early 1970s, there emerged in Chile a new musical expression: Chilean Psychedelic Rock. This music, characterized by its strong hybridization of psychedelic rock elements with Kichwa, Aymara, Mapuche and Afro-descended Latin American musical forms, articulated itself from a particularly situated Andean geocultural locus of enunciation. Through a musical act of transculturation (Ortiz 1995), this 
music made audible a sonorous form of border-thinking. In what follows, we propose that the musical and countercultural phenomenon led by Los Jaivas and other bands is one of the points of origin of a liberation of aesthesis that occurred in Chile in the 1970s. This article argues that the music, lyrics and visual elements created by bands like Los Jaivas helped to trigger an important displacement in cultural attitudes (MaldonadoTorres, 2016) that unmoored eurocentred conceptions of affect, attitude, behaviour and relationality in Chile in a way that persists until today.

Following Walter Mignolo's work on aesthesis, and putting it in dialogue with concepts from the oeuvre of philosopher Rodolfo Kusch, we argue that the early work of Los Jaivas, and in particular the self-titled album commonly referred to as El Volantín (1971), contributes not to a strictly political discourse, but rather to the creation of a decolonial attitude. Thus, in the early work of Los Jaivas, both countercultural and decolonial attitudes coexist and work together to create a new musical expression. This attitude enacts an alternative aesthesis and works to free the Chilean subject from the restrictive normativity of eurocentric aesthetic values. In this way, the work of Los Jaivas creates a bridge between the global countercultural movement of the 1960s and, through its body of lyrics, identifiable sonority and corresponding visuals, the experiences, affect and sensibility of Chilean subjects undergoing decolonial processes.

Decolonial aesthesis forms part of a larger project of unlearning the epistemic privileges of modernity (Mignolo 2002) and relearning what was hidden by the discourses of modernity (Dussel 1992). Decoloniality seeks to question the discourses of modernity in order to explore and re-live other ways of being in and understanding the world (Escobar 2007). This involves, as Walsh (2018) explains, responding "to coloniality and the ongoing colonial process and condition. It is a form of struggle and survival, an epistemic and existence-based response and practice [...] for the possibilities of an otherwise."

\section{Why Chilean Rock?}

In the fields of musicology and the sociology of music in Latin America, with the notable exception of Argentina (Favoretto 2014; Pujol 2005), in the case of Chile at any rate (Salas 2003; González 2013; González 2012; Ponce 2008; Barr-Melej 2017), the music and the cultural practices associated with the rock genre have been left to be addressed in the fields of journalism, biography, and history (Stock 2014). Instead, much of the scholarly attention in Chile has focused on a musical expression that, parallel to Chilean Psychedelic Rock, also emerged in the Chile of the 1960s: the Nueva Canción chilena (Barr-Melej 2017). As a result, many Latin American scholars still consider rock music and pop(ular) culture to represent ideological and cultural products linked to the institutions, and to the logic and practices of production and consumption of capital, despite its deep roots in African-American experiences and practices of resistance (on this, see Davis 1998; and Garon 1996).

This article shows that Chilean rock is a symptomatic expression of the crisis of values underlying the Colonial Matrix of Power (Quijano 2000; Mignolo 2011), despite its links to a global countercultural phenomenon. Quite apart from its undeniable status as a consumer product, it constitutes an effective plateau that has allowed several generations of Chileans to enact an epistemic delinking of a political-identitarian resistance to the dominant liberal values.

Chilean rock, without a doubt, shares in the countercultural spirit of youthful rebellion that occurred in the context of what Vega Cantor and Bosenberg defined as being a "década de grandes intentos de emancipación" ("a decade of great strides towards 
emancipation"), in which thousands of youths challenged "los fundamentos morales de la sociedad mayoritaria" ("the moral foundations of mainstream society") in an attempt to "trastocar todos los valores" ("subvert all of its values") (2009: 150). However, in the Chilean case, this is further tempered by a moment of questioning, spurred by a generalised discontent with the status quo manifested on several levels: through political struggle; in a global 'third world' moment of liberation and anti-imperialist struggle; and through the rearticulation of the social and behavioural codes marking the counterculture, evidenced in new forms of dress, and novel forms of relating to one another through communitarian imagination. Consequently, Chilean Rock is undoubtedly connected to, and forms a localised variant of a global countercultural phenomenon (Barr-Melej 2017), but it differentiates itself from that phenomenon by highlighting, through its lyrics, music and visual aesthetics (Grunfeld 2007), the enacting of other ontological ways of sensing, operating, and relating. In other words, although Chilean Rock forms part of a global countercultural moment, it also brings forth an attitude whose roots emerge from a grounding in Chile's Indigenous cultures. In this sense, though it may share electric instrumentation, it seeks to disconnect itself from any notion of a global or cosmopolitan culture, as understood from the centres of power (Mignolo 2011; Holas \& López Castellano 2020). Instead, it articulates itself through its grounding in and conversation with (reflection on and exploration of) its own Indigenous roots, something that had previously remained at the margins of mainstream Chilean sensibilities.

Taking up the metaphor of La ventana from the second LP by Los Jaivas (1972), this paper is organised into two sections, each one with short subdivisions. In the first, we consider briefly the difference between aesthesis and aesthetics, and discuss Rodolfo Kusch's insights about the distinction between estar and ser (both terms translate into English as to be, however Kusch makes some important distinctions between them, the nuances of which we explore further in the following pages) as the two modes of being that are intrinsic to Latin America. In the second, we investigate how this distinction between estar and ser works in three songs by Los Jaivas, arguing that a decolonial aesthesis is enacted in them at the musical and lyrical levels.

\section{Aesthesis first, then its expression in a decolonial aesthetics}

Through their musical, lyrical, and visual work, Los Jaivas open the door for a more diverse way of sensing, operating, and relating; one which acknowledges the influence of the Kichwa, Aymara, and Mapuche nations on Chilean culture, affect, and values. Prior to the emergence of Chilean Psychedelic Rock, Chile's dominant affective disposition and sense of taste, from the colonial era through to the twentieth century, had mimicked European values, aesthetic norms, behaviours, and customs. This emulation of European cultural norms restricted notions of what could be considered aesthetically acceptable and of good taste. It also resulted in re-classifying as folk, craft, or non-art the variety of expressive forms of Indigenous nations and of the Chilean people more generally, creating a hierarchy of expressions, and limiting sensibility (López 2014; Mignolo 1992).

In this context, the work of Los Jaivas constitutes an act of decolonization with respect to the predominant aesthetic values of the Chilean nation. In this, they enact something akin to what Walter Mignolo and Rolando Vázquez have identified as decolonial aesthesis: 
Decolonial aesthesis starts from the consciousness that the modern/colonial project has implied not only the control of economy, the political, and knowledge, but also control over the senses and perception. Modern aesthetics have played a key role in configuring a canon, a normativity that enabled the disdain and the rejection of other forms of aesthetic practices, or, more precisely, other forms of aesthesis, of sensing and perceiving. (2013: n.p.)

The point here is to liberate aesthesis and sensibility from the constraints of modern aesthetics: aesthetics needs to be decolonised to undo the forces exerted onto subjectivities to make them conform to the state's image of citizenship and civility (Mignolo 2010a). When liberation from Eurocentric aesthetics is enacted, a decolonial aesthesis makes possible the resurgence of other ways of sensing, operating, and relating to the world.

Decolonial aesthesis addresses those practices made invisible, inaudible, untouchable, and even considered to have an hedor or "stench" (Pérez 2013: 31-38) by the institutions composing the colonial matrix of power. As a result, aesthesis can be understood as a practice in which negated ways of sensing, operating, and relating can re-emerge. This is precisely what is at stake in the early work of Los Jaivas, who, using the psychedelic rock format, explore sonorities and ideas that had been, for centuries, devalued and silenced, bringing these into the mainstream of Chilean culture. In the case of Los Jaivas, the decolonial aesthetic act is musical and epistemic, as it is tied to the band's highlighting of Indigenous sonorities and lyrical ideas that problematise inherited social values.

The songs of Los Jaivas are enunciated from the perspective of a subject that questions the predominant social norms and, in doing so, looks to the wisdom and experience of Chile's Indigenous people as providing an alternative perspective. This reflects what Walter Mignolo has recognised as a shift in thinking "from or a partir de imperial experiences and subjectivities (...) to the experience of the colonial subject" (Mignolo 2010b: xxxvi). In what follows, we discuss and explain Rodolfo Kusch's insights into the modes of ser, estar and estar-siendo, before engaging directly with the songs in the second half of the article, to understand better how the work of Los Jaivas performs this epistemic shift.

\section{Kusch: from ser and estar to estar-siendo}

From the publication of his first book in 1953, and until his death in 1979, Kusch interrogated issues centred around the specificity of Latin American thought. Trained in continental philosophy, Kusch observed that we Latin Americans are unable to answer questions about our own social realities without using our own critical tools. After all, our "geocultura" is not identical to the European one whose conceptual tools we use to understand, interpret, and shape reality, ourselves, and our societies. For Kusch, the issue is "not to negate Western Philosophy, but to look for a formulation closer to our own lives" (Kusch 2010: 1). Referring to the salient ideological debates of the 20th century, Kusch explains that in an American context:

All of that lacks meaning because it never tells the truth. In reality, these are the channels through which Americans funnel their opinions without noticing that the orientation they give to their thinking constitutes the main barrier to understanding the real way of life to which they belong (...) they are nothing but the thinking of an enterprising middle class, situated in the coastal cities of the continent. Opposed to them stand a relatively inert and hostile pueblo (Kusch, 2010: xxvii) 
The problem that Kusch encountered was that European theories had, since the colonization of America, been considered universal, to the detriment of all other knowledges. In his ground-breaking essay "Power, Eurocentrism and Latin America" Aníbal Quijano notes the importance of this process as a constitutive element of the global division of labour along racialized lines:

Europe's hegemony over the new model of global power concentrated all forms of the control of subjectivity, culture, and especially knowledge and the production of knowledge under its hegemony [...] they repressed as much as possible the colonized forms of knowledge production, the models of the production of meaning, their symbolic universe, the model of expression and of objectification and subjectivity. (2000: 541)

This process cast native nations as backward and non-modern in the European causallineal perception of time. Thus Mapuche, Aymara, Kichwa, and other Indigenous groups became delegitimised and relegated to a pre-European past by the intellectuals of their very own countries (Quijano 2000: 542), who turned to Europe for models of knowledge and social organisation (Grosfoguel 2011). Once this epistemological hierarchy was broadly accepted and upheld by Latin America's institutions, we saw ourselves exclusively through categories not of our own. Later, these same prejudices, filtered through the notion of class, came to affect our aesthetic sensibilities.

In this context, Kusch had to question and displace the linearity of his own colonised gaze, and, in order to philosophise from Latin America, Kusch radically questioned the terms of the conversation, based on his own embodied experience and "mestizo" or "immigrant consciousness" (Mignolo 2010b: xv). This embodied experience of sensing (aesthesis), operating (knowledge), and relating (relationality) allowed him to engage with America's Indigenous traditions and to critique the Eurocentric perspective of his own philosophical discipline. Mignolo explains the implications of this shift:

While European thought names the imperial epistemic frame, American thought names the presence of European epistemology, but analyzed from the perspective of the immigrant consciousness taking on Andean (mainly Aymara) epistemology (...) "thinking from" Indian philosophy instead of "thinking from" Greek philosophy. (Mignolo, 2010b: xxxiv)

Kusch thus took the Heideggerian preoccupation with being (Dasein) and, elaborating on his own situated experience, articulated that, in America, there was a complex tension between two different forms of being: estar which was linked to Indigenous worldviews; and ser linked to the dominant European worldview. Kusch argued that, in fact, what the Latin American subject (neither European nor Kichwa, Aymara or Mapuche) struggled with was the tension between these two seemingly opposing worldviews. To resolve this tension, Kusch crafted the term estar-siendo, employing the gerund to express the present and embodied nature of this experience. It is this sense of estar-siendo that Los Jaivas articulate in their early works.

In trying to understand the experience of being Latin American, Kusch realised that the experience of Latin America's middle classes and of the many new European immigrants of the 20th century was developed around urban centres. Cities were invested with the positive attributes of safety and cleanliness (pulcritud in Kusch's parlance), to the detriment of the countryside, which was perceived as a barbaric place. Mirroring the European social model, the predominant logic of the cities was an urban economy, "an urban cultural structure based in a causalist thinking, limited to intellection, volition, the depersonalization of science, and the myth of the solution" 
(Kusch 2010: 126). Whereas, in the countryside, despite the centuries of colonialism, he perceived the Kichwa and Aymara in the northeast of Argentina as having a wholly different form of sensing, operating, and relating, which he called "seminal" (Kusch 2010: 124-134), and which was characterised by "thinking through inward directedness which personalizes the world" (Kusch 2010: 126).

It was seminal in the realisation that, when sensing, operating, and relating, the Kichwa and Aymara intended to conserve their conversation with their gods. This conversation would assert itself through expansive forms affirming relationality, such as ceremonies, prayers, rites, songs which expressed their aesthesis (sensibility) and in practices of observing for changes both within and outside, gazing at the signs issued by the gods (thunder, rays, rain, wind, wetness, dryness) so as not to alter the conversation with the Pacha ("world"). All of these forms conveyed a circular way to sense, feel, and conceive of time, avoiding extreme dichotomies and the imminence of chaos. They also aimed "to reconcile the torn extremes to which the experience of life is ultimately reduced" (Kusch 2010: 131). Kusch thought that the desire to nourish dualism or balance, most recently articulated as homeostasis (Monsalve 2013), was well shown in the Castilian form of the verb estar, one of the two verbs used to express the idea "to be" (the other being ser).

Estar, the specific form of being in the world of the Kichwa and Aymara nations, required careful observation of the forces within the self, avoiding "going into extremes" (Kusch 2008. 26). Hence estar comprises a worldview that has two sides in need of equalising, giving the subject the responsibility of balancing the forces of life. Therefore, there is an analogic process between natura (nature) and man/woman's psychic processes, requiring our full attention, resulting in the integration between human psyche and the cosmos. The second form of the verb in Castilian, ser, conveys a different form of activity directed exclusively to what is perceived as external to the subject. In short, ser represents "the triumphal and persuasive rhetoric of being: being as success [being successful], being someone, being on top of another [...] it is precisely this sense of ser alguien (being someone) as fulfilment that Kusch contrasts with estar" (Mignolo 2010b: xlix). As we shall see in what follows, the compulsory paradigm of ser is the same one that Los Jaivas negate in "Indio hermano" and other songs.

The most profound of Kusch's insights is that estar persists today in the experiences of the people (Kusch's "el pueblo"), which includes Latin America's rural population and urban popular and middle classes. For Kusch, the many city dwellers that don't seem to fit in with the haste of modernity contradict themselves: they desire to "be someone", but they also often negate that desire:

It is not the man created by the European bourgeoisie, but rather that other man, besieged by the police and the military, susceptible to being counted statistically, obliged to vote, someone to whom opinions are attributed, opinions not heeded by anyone, and to whom a monthly salary is assigned. And all of this is done to certify convincingly his heroic humanity; which, at base, everyone doubts. [...] It is, in the end, an estar reduced to inhabitation to here and now and materialized nebulously as something around which everything turns. (Kusch, Indigenous and popular 163)

For Kusch, this contradiction, key to understanding the Latin American urban experience, articulates itself as a form of resentment and is expressed as an attitude of negation which works to neutralise ser through what he called a process of "phagocytosis" of ser by estar. The end result is an urban culture whose mode of being is estar-siendo. That is to say, a culture where two modes of being coexist. 
Having stated the conceptual tools that inform our argument, and discussed the context from which they arise, we will move now through a reading of three songs by Los Jaivas. Our aim is to demonstrate how these songs create two major changes: they employ an impure, transcultural musical language that, taken together with the lyrics and visual aesthesis of the band, constitutes an embodied and grounded sonority that emerges from the consciousness of our estar-siendo: and they instantiate a decolonial attitude.

\section{Los Jaivas: the resurgence of estar from beneath ser}

Los Jaivas' cover art and album titles reflect their particular loci of enunciation. They are loaded with visual references to the Andean mountains and other figures inextricably linked to the Southern Cone. For example, the self-titled album known as El Volantín shows a children's kite made out of a Chilean flag, accompanied by a drawing of a green field surrounded by the sea. Likewise, the very first melody on the album is intoned using a quena and a trutruca, autochthonous instruments belonging to Chile's native cultures (1), and the song's rhythms are marked by a cultrún and bombo, pointing to an alternative conception of what Chilean culture might look like by emphasizing its southern locus of enunciation.

We argue that this turn towards the Andean south implies a strong identification with what Rodolfo Kusch has identified as the mode of estar. For Kusch, estar is a key element at the base of mestizo conscience in the Southern Cone, as he identifies at the core of this a duality of attitudes, moods, and worldviews. This is manifested in what he defines as the tension between the active ser of the European migrants and the introspective estar of the Indigenous Andean cultures, articulated as a slow process of "phagocytosis", forever frustrating the efforts of the political elites to become fully European on American soil.

We identify this process of phagocytosis as one of the drivers and key strategies employed in the work of Los Jaivas. This phagocytosis can be heard in their musical and lyrical practices, as well as in the aesthetics of the visual imagery on album covers, and overtly salient in the lyrics of Todos juntos (1971) and Indio hermano (1972).

In the late 1960s, Chilean Rock re-situated itself: gone were the cover-versions of songs sung in English and the romantic, adolescent generic conventions of rock' $n$ 'roll. Instead, Chilean bands embraced the Spanish language in order to explore situated and existential themes, and brought to the fore native Andean melodies and Mapuche rhythms as well as folkloric musical forms, hybridising these with those of rock music within the context of electric instrumentation.

Chilean Rock bands of this time period also explored issues pertaining to identity, to place, to the role of youth in Chilean society, by bringing forth a musical language situated in the estar-siendo of the Chilean experience. Kusch's interlacing of the affective dispositions and attitudes encapsulated in his concepts of estar and ser reveals precisely the peculiarities of America's inhabitants, as shaped by geography, the colonial experience, and Indigenous resistance and worldviews. The music of Los Jaivas allows us to explore this dynamic, as it paves the way for other forms of sensing, operating, and relating, no longer as that of the "copia feliz del Edén" ("a happy copy of the Garden of Eden") signalled by the Chilean National anthem, but rather as a coherent intertwining of these two concepts, in the unstable steadiness of estar-siendo. 


\section{The songs}

In the case of Los Jaivas, especially in their earliest works, we argue that they were enacting an aesthesis, that is, a sensibility that amplifies the expressive capacity of the rock genre, contributing to making visible the situated Andean and Mapuche roots of Chilean culture. In what follows, we explore, if briefly, the possibilities produced by this aperture, concentrating our analysis on three songs from the early works produced by Los Jaivas. The selected songs will correspond to those that most clearly articulate and illustrate a shifting perspective with respect to Chile's relationship with the cultures of the Andes: "Cacho" (1971), which we will put in dialogue with "Ayer caché" also from 1971, and "Indio hermano", their first single, later included in La ventana, their 1973 LP. (2)

\section{"Cacho" or the invocation}

"Cacho" is the first song on Los Jaivas' first album. This song, consisting of thirty-two verses, forcefully opens a space in which to re-consider the roots of Chilean identity. It does this by connecting with and contributing to the re-emergence of a way of being in the world that had been changed by colonization. This negated voice is, we contend, the estar mode of existing in the midst of a sacred world, which shapes the sensitive relational disposition of the being in the world of the Indigenous people of the Southern Cone. This precarious voice emerges from the silence of a negation dating back to the arrival of Europeans in 1492, which resulted in the imposition of the European models of subjectivity.

In this context, it is notable that the song activates a sonorous inversion of the historical-colonial order. The song is an improvisation that begins with a brief introduction played on the piano, in the form of a passing melodic allusion to a waltz. However, the song produces a juxtaposition as the piano slowly fades, displaced by wind instruments belonging to both Kichwa and Mapuche instrumentation, in which a tarka intones the melody, with periodic interventions performed by a trutruca, while percussion instruments keep a steady rhythm. Having set the scene with this inversion, the song goes on to incorporate western instruments, such as an electronic organ and acoustic piano, which take up the melody that had been carried by the wind instruments, while the percussion demarcates a rhythm that has a clear debt to Mapuche musical traditions. In sum, Western instruments are placed at the service of an Andean melody, backed by a Mapuche rhythm, which serves as the basis for the singer's lament, which takes the form of a huayno (also waynu), an Andean genre of music and dance related to Bolivia, Perú and the northern regions of Argentina and Chile.

The vocal section of the song begins with a voice that is seemingly arising, phrase by phrase, from a metaphorical darkness, and it seems to continue an unfinished song, cutup, fragmented, and mournful. This voice stutters its way into the first verse by enunciating a song (through both form and content) that refers to a time prior to the arrival of Europeans. The voice begins to weave its chant precariously, using phrases and verses that at times seem incomplete and jarring, as if emerging from an unfamiliar origin. Herein lies the heart of the song: this attempting to re-articulate itself from the locus of enunciation of a prohibited family, an almost destroyed memory or genealogy. The song emerges from the point of view of a singer subjected to a process of schooling and of acculturation that denies the ontological possibility of estar and of the sensibilities, ways of operating, and of relating based upon it. This precariousness is formalised by the singer's use of the past imperfect verbal form, which implies an unfinished, though recurring action: "...que solía ser...una que decía...yo quería ser una que decía..." ("I 
used to be...one who would say...I wanted to be one that would say"). In this manner, the song evokes the presence of a form of "being" in the world that colonization had negated and reduced to a form of "non-being" (Grosfoguel 2011).

In thematic terms, the song explores the act of becoming aware of the persistence of estar within the self, of the desire to de-link self from the compulsory mirror of modernity, and the re-existence of that sensibility and form of singing that had been relegated to the zone of non-being. It is in this context that the embryonic singer manages throughout the improvisation to ask the crucial question: "Por qué no puedo ser como yo quiero? ("Why can I not be as I want to?"). By asking this, the song calls for the resurgence of Kusch's estar, which had been placed under the line of being, losing its validity and thus its presence. The past becomes a force to liberate self from those hegemonic images that imprison the singer into a specific type of representation that does not account for his relation to the Pachamama. The following verses of the song explore this conflict in the embodied experience of the singer, who dwells within the contradiction.

The desire to move away from this negation of the ontologies of estar and estar-siendo, and the obligation to mimic a Eurocentred model, is the point from which the early work of Los Jaivas departs. Their aesthetics breaks away from the obligation to repeat a model imposed through the process of colonization. The question asked by Los Jaivas, "por qué no puedo ser como yo quería" ("why can't I be as I wanted?") has, in this context, two particular consequences: firstly, that the singer's voice is expressing dissatisfaction with Chile being conceived in the image of the Garden of Eden; a copy aligned with Eurocentric values. And, secondly, that the singer's negation points toward the colonial wound and the resulting difficulty of articulating the desire to be different. In this respect, the song is an attempt to look for answers in another memory, which indicates the need to turn backwards in order to see an alternative future more in tune with the grounds from which he is articulating his song. The singer sings with his back turned against the "future splendour" promised by Chile's national anthem, and instead seeks the deeper roots of his identity in the shattered memories of the Indigenous. The singer's gesture is of respect and acknowledgement of those repressed elements of his own mode of estar. Stated differently, what the singer is doing is learning to respect and love himself, hence his need to make space within himself to relink with those negated memories; to re-exist, in order to conserve homeostasis and thus health.

In a twist, in order to discover the answers to his own questions, the singer must be willing to "listen" (Kusch 2008; Lenkensdorf 2008; Vázquez 2012). Escuchar is a requirement of the singer's necessity to relink with those memories at the root of his sense of identity. The song invokes "ser como yo quería" ("to be as I wanted") to imagine the world otherwise. This notion of listening is in contrast to the model imposed by the Spanish colonisers and the subsequent European migrants, who have issued demands and mandates of obedience, but have not engaged in listening to the native nations. As Kusch reminds us, "la cuestión no radica en mandar, sino en escuchar al que recibe las órdenes" ("the issue is not to give orders, but to listen to those who receive them") (Kusch 2008: 13).

Listening is a constitutive characteristic of the estar mode, given that it is necessary to listen in order to have a conversation with the gods and with others. It is this very disposition towards listening and maintaining a balance in one's participation in the world that was made impossible when the European colonial order was established in Latin America. The colonial administration privileged writing instead of listening, because writing exteriorizes the internal thought processes of the subject, making these impersonal, abstract: a precondition for European thought's self-ascribed pretension to universality. After all, the Eurocentric conception of being, exemplified by the "egoconquiro" which is the seat of Descartes' cogito, ergo sum (Dussel 1992: 56-75), lays 
the basis for a type of imperial rationality and a narrow view of the world's diversity which prioritises writing over orality (Ong 1992).

The precariousness of the listener's position in the Western world is not fortuitous, as it displaces the priority from the eye and representation, and instead places the ear at the centre of their world. This displacement from the eye to the ear has radical consequences for citizens of the nations of America, as it necessitates recovering or relearning ways of sensing, operating, and relating in the world. This implies, at the same time, an inverse process of unlearning the certainties produced by the discourses, disciplines, languages, and behaviours inherited from Europe. In order to listen, one must acknowledge, at the level of affect and disposition, the need to listen to one's own memories. Subsequently, in appealing to another image of what it means to be human (Wynter 2003), affect, here, becomes a desire to re-exist in relation to all of life. This opening makes possible the undermining and change of the terms at the very interiority of the she/he who occupies the position of the subject. In order to learn from the other culture and from the person that lives in that other language, it is essential to vacate the position of the subject and stop commanding what truth is.

Between verses one and ten, the song manifests the precariousness of this question about the other, and the notions of what is sought after and has been negated. These early verses of the song already affirm the desire, as well as the precariousness and the difficulty of singing this bridging, and of trying to return to harmonise the two sides of the self.

From verses eleven through to twenty-nine, what is enunciated is the desire to change. In these verses, that great cataclysm that was the arrival of the Spaniards and the denial of other forms of life are sung, with particular reference to the denial of the estar mode, through the line: "que no sigamos viviendo" ("that we should not continue to live").

However, there is also a reversal in the fabric of time, as this negation is taken into the present. In this, the song raises the question of temporal linearity, pointing to the present-day denial of indigenous knowledge, and to their relegation to the past; to a state of prehistory with respect to modernity.

The song concludes by asking, contradictorily: “Cómo queríamos ser? / cómo queríamos ser / ...no pude ...donde...síí..." ("How did we want to be? How we wanted to be / ... couldn't... where I was"), opening a space which puts into question the requisite ser mode of modernity, and modernity's hierarchical ordering of cultures into a linear-time, placing the West at the forefront, situating all other cultures as its prehistory. By asking some fundamental questions about what lies at the base of their own negated identity, Los Jaivas attempt to start their singing from the very depth of the colonial wound, a song that reveals the persistence of other modes of being.

\section{"Ayer caché"}

"Cacho" is intertextually linked to "Ayer caché", from the second Los Jaivas LP, selftitled, but popularly known as La ventana ("the window"), due to the drawing of an open window on the cover of the LP, which is associated with the capacity to see through it, into another landscape denoting birds flying in a blue sky. On the back cover, you also have a window looking through into a landscape full of animals, trees, and the members of the band, all coexisting peacefully. This back cover is characteristic of the estar-siendo conception of reality. In this conception, there is no empty space, or time, as all of it is crowded with images and sounds of living and non-living beings. There is an intertextual play between the lyrics of "Ayer caché" and the images that compose the LP cover.

"Ayer caché", a short song consisting of two stanzas made up of twenty-eight verses, is a bolero performed with electric instrumentation, and its percussion tracks are played 
with the aid of Afro-Latin American instruments. The title of this song makes a clear reference to the verb cachar, referring to the common Chilean usage of it to express the ideas "to realise" or "to notice", and it expresses the idea "yesterday I realised". In the song, this action of realising is paired with a set of contemplative lyrics that evoke the experience of a subject who is, for the first time, realising that their identity and everyday experience are marked by an Andean landscape and by "el amor" (love) (Verden-Zoller 2003). If the song title refers to the notion of a sudden realisation, the song's lyrics turn to how this realisation is the effect of opening up one's senses to one's surroundings. The poetic speaker characterises this realisation as the dawn of a new day, "que la luz llega al amanecer" (with the morning light). This morning light allows the poetic speaker to see with clarity, the elements that are essential to and make up his world, all of which belong to the landscape: "los pajaritos", "el cielo", "la tierra", "las colinas", "el agüita", "la Iluvia", "mar azul" ("the birds, the sky, the earth, the hills, the water, the rain, blue ocean"). In this sense, the song suggests that if one shifts one's perspective away from the angle imposed upon the subject by the West, then one can also comprehend that affect and emotion, shaped by place, have their own logic, one that calls into doubt the logic of instrumental reason. Indeed, the song points in the direction of the recognition of an affective disposition (sense) towards the world negated by imperial reason: "la risa", "el beso", "un sueño por el tiempo... por el tiempo bueno", "con las historias que nos cuentan", "con los que vendrán a vivir con nosotros" ("laugh, a kiss, a dream for the good time, with the stories that they tell us, with those who will come to live with us").

Ultimately, to cachar allows "las cabezotas duras" ("the hard-headed ones") to realise that existence is not entirely abstract and utilitarian, but as the song suggests, made possible through the weaving of love and place. It is of little wonder that love does not refer here to romantic love or Christian love, but rather is conceived as a biological force that magnifies the senses, allowing one to perceive with intelligence and beyond the prejudices of logic and reason (Mignolo 2018: 213). If reason is expressed as that which limits the ways in which one can be in the world, then the song expresses the need for another way of understanding (knowledge): "para que nunca más... tengan que $i^{\prime \prime}$, "para que nunca más... donde no quieren ir", "para que nunca más tengan que ser" (so that they will never again have to... go or be). These notions connect intertextually with the questions about being asked by the singer in "Cacho". In our reading of these songs, the question about being expressed in the verse "ipor qué no puedo ser como yo quiero?" begins to be answered in "Ayer caché", which expresses the importance of situatedness, and which opens a trajectory that is culminated in "Indio hermano", in which the speaker turns to Chile's indigenous cultures for knowledge.

\section{"Indio hermano"}

If "Ayer caché" constitutes, in our reading, an important moment in Los Jaivas' path toward decolonising understanding, unquestionably, this attitude is developed to its fullest expression in the song-manifesto "Indio hermano" (incidentally, the band's first single). In "Indio hermano", a song composed of five short stanzas (some of which, like the chorus, are repeated), the decolonial question takes on full significance. Its twenty verses provide an account of the new geocultural locus of enunciation of the singing subject, who now assumes a position of complete resistance to the negation of those other ways of existing that constitute the modes of estar of the Kichwa, Aymara, and the Mapuche nations. The song tells the story of that shifting perspective, as the singer declares "mi destino es resistir" ("it is my destiny to resist"), as a result of the suffering brought forth by this civilization "engañado, solo, triste y sin amor" ("misguided, alone, 
sad and without love"). We find that the singer now totally embraces the wisdom of the Indigenous cultures of Chile, as the song appeals to "hermano querido indio de aqui" ("dear brother Indian from this place") to whom he becomes an apprentice. This, in the Chilean context, takes on a radical significance, as it inverts the social and epistemic order maintained in the region since the arrival of the Spanish.

The vocalist, in order to sing with his voice embodied and situated in its own ground, and not in that of the abstract-universal European subject, must first learn to listen, abandoning the commands of Cartesian rationality. This displacement is a necessary step in the road to self-discovery of the Chilean subject because, as we have seen in the song Cacho, the autochthonous mode of estar has been negated by the dominant Eurocentric culture. The point here is that the dominating conception of culture has itself been imposed upon the Chilean subjects who, like ventriloquists, repeat it: "soy un hombre no una pieza más de esta cuestión" ("I'm a man not just another piece of this thing"). It is in answer to this awareness that the singing subject situates himself in a position in which he is willing to listen and learn from the "indio de aqui" ("Indian from here") who now takes on the position of a person, a brother, who knows and is of epistemic stature and density. This shift is, of course, of key importance and a necessary pre-condition to any liberating and decolonising processes: the nations of Latin American must escape the mirror of representation, and no longer define themselves as nations repeating a foreign image of the self. The inversion put forward in "Indio hermano" therefore illuminates a mode of being that is inextricably linked to being situated "here" (estaraqui), embodied and related to this earth and, as a result, affirming a long-standing resistance with respect to the imperial modes of being.

The song's chorus attests to the singer's change, as he learns, from his indigenous brothers, to resist "esta civilización de poder y de ambición" (this civilisation of power and ambition). The singer's resistance is, as a result, an effort both to negate the negation of 500 years of the dominant culture's impositions, and to bring forth an image of humanity that is otherwise. Here the singer recognises that it is the "indio hermano" that has helped to "revive in his own chest the flame of liberation": "tú me has ayudado a revivir la llama de la liberación" ("you have helped me to revive the flame of liberation"). In this way, the act of realisation present in "Ayer caché" is extended in "Indio hermano" to include a process of listening to Chile's indigenous stories, knowledges, and ways of being. This act of listening expands the understanding of what it is to be Chilean.

The decolonial impulse in "Indio hermano" doesn't only lead to a series of inversions that take place at the textual level, but rather, these are echoed in the song's sonority, as well as in the decolonial aesthetic of the covers. Notably, the song follows the pattern of a pasillo andino, marked by a percussion heavily influenced by the diabladas (3) from the Andean highlands. Ultimately, the song has heterogeneous instrumentation, which includes the use of charangos, bombo, pincuyo, tarka, electric, acoustic and bass guitars, as well as a drum-kit, accompanied by various other percussion instruments, all of these put in the service of indigenous rhythms and melodies, dislodging the rock genre by transposing it onto Andean soil, and grounding it in its rhythms and memories.

\section{Conclusion}

The first two albums by Los Jaivas seem to mark a profound moment of change in Chile, initiating, at the cultural and identitarian level, a profound shift, impelled by the inauguration of a decolonial aesthesis expanded in their aesthetics. This shift enacted by Los Jaivas opened up a space for the recognition of ontological and epistemic processes 
that highlighted the estar mode, which, together with the European ser, located the affective disposition of Chile's mestizo estar-siendo. In making this shift, Los Jaivas enacted a reversion of a history of centuries of negation and repression. In our reading, "Cacho" represents the breaking open of the colonial wound, from which singing becomes a meaningful and truthful possibility. "Ayer caché" states the affirmative characteristics of realising that to be alive is also to be situated (in the Andean south). "Indio hermano" states the importance of listening to those knowledges and ways of being repressed by coloniality.

The lyrics of the songs bring forth an epistemic de-linking that opens into another way to express a Chilean sense of identity. This process, in the context of popular music, acknowledges both the politics and the aesthesis of the Kichwa, Aymara, and Mapuche nations as part of the memories and practices that shape Chilean identity. The popularity of the rock genre, as well as the visual, sonic, and textual work that the songs by Los Jaivas present, make visible these indigenous roots, and enact a transformation of the Chilean subjectivity and cultural horizon.

This act of de-linking, however, does not only occur at the textual level but rather can be found throughout the musical components of their first few albums. Los Jaivas' first handful of albums incorporate a series of American musical traditions into a fusion with the rock idiom: Andean melodies and rhythms, Chilean folk music, boleros, pasillos, and Afro-Latin American rhythms. Although the group relies heavily on a typical rock group instrumentation, featuring electric guitar and bass, drum kit, vocals, and keyboards, it also incorporates instruments that are autochthonous to Chile and the Andes. The songs analysed here, for instance, employ Andean wind, chorded, and percussive instruments. Rather than following a typical rock progression (based on the I-IV-V chord structure of the blues), many of the songs have, as their central motifs, melodies based on Andean instruments and tunes. "Cacho" and "Indio hermano", for instance, employ some of the patterns of the huayno. "Ayer caché", in turn, reflects the influence of Afro-Latin rhythms, including the bolero rhythm, and even incorporates the sounds of an ocarina, showing the band's commitment to crafting an autochthonous rock-idiom.

As we have demonstrated, the early work of Los Jaivas constitutes an act of epistemic disobedience, and develops a decolonial attitude. This attitude re-links estar and ser in estar-siendo, moving away from the extreme dichotomies produced by our Eurocentric modernity.

\section{Endnotes}

1 The quena is a wind instrument from the Andes, belonging in particular to the Kichwa culture, and the trutruca is a wind instrument of the Mapuche people of the South of Chile. A cultrún (also kultrung) is a Mapuche drum made of wood and animal skin. A bombo in Spanish commonly refers to a bass-drum, however in the Andes it refers to a large drum traditionally made with cured animal skins with the fur left on the drum-skin. Later in the text we also refer to the following instruments. A charango is a stringed instrument from the Andes. Traditionally made from the body of an Armadillo, it is now produced from wood and has at least five sets of doubled strings, often more. A pincuyo (also pinkillu, pinquillo or pincullo) is a flute that is commonly played in Argentina, Bolivia, Chile, Ecuador and Peru. It is designed so it may be played with one hand (allowing the player to accompany the flute with a drum).

2 For Cacho's lyrics, see https://www.musixmatch.com/lyrics/Los-Jaivas/Piano-introducci\%C3\% B3n-Cacho. For Ayer caché's lyrics, see https://www.letras.com/los-jaivas/571741/ For Indio hermano's lyrics see https://www.letras.com/los-jaivas/570839/

3 Pasillo is a genre of music from the Colombian Andes, related to a waltz, but played with an Andean instrumentation; it is related to the independence era of the $19^{\text {th }}$ century. A diablada is 
a style of dance, with an associated style of music, which is practiced in the Andean countries of Peru, Bolivia and Chile and thought to have an Indigenous Andean history, although at least from colonization onwards, the dance has incorporated Christian iconography.

\section{References}

\section{Bibliography}

Barr-Melej P. 2017. Psychedelic Chile. Chapel Hill: The University of North Carolina Press.

Bosemberg LE and Vega Cantor, R. 2009. El 68 Revolución o Rebelión? Revista de estudios sociales 33: 148-155.

Davis A. 1998. Blues Legacies and Black Feminism. New York: Pantheon Books.

Dussel E. 1992. 1492. El encubrimiento del otro. (Hacia el origen del mito de la modernidad), Bogotá.

Escobar A. 2007. Worlds and knowledges otherwise: The Latin American modernity/coloniality research program. Cultural Studies 21: 179-210.

Favoretto M. 2014. Charly en el país de las alegorías, Buenos Aires: Gourmet Musical.

García LB. 1991. El Imperio Contracultural: Del Rock a La Postmodernidad, Habana: Editorial Arte y Literatura.

Garon P. 1996. Blues and the poetic spirit, San Francisco: City Lights

González JP.

2012. Vanguardia Primitiva En El Rock Chileno De Los Acos Setenta: Música, Intelectuales Y Contracultura. Música Popular 1: 75-92.

2013. Pensar La Música Desde América Latina, Buenos Aires: Gourmet Musical.

Grosfoguel R. 2011. La descolonización del conocimiento: diálogo crítico entre la visión descolonial de Frantz Fanon y la sociología descolonial de Boaventura de Sousa Santos. In: Macé AVB (ed) Formas-otras. Saber, nombrar, narrar, hacer: IV Training Seminar de jóvenes investigadores en Dinámicas Interculturales. Barcelona: CIDOB edicions, 97-108.

Grunfeld MP. 2007. Proyecto Editorial: Carátulas Del Grupo Musical Los Jaivas. Testimonio Histórico, Reflejo De Identidad E Imagen De Marca. Santiago Universidad de Chile

Holas, I. and Castellano RL. 2020. Transitional Music: Popular Music as Agent of Social Change in Chile and Spain. Journal of Iberian and Latin American Research 26: $100-114$.

Holas S. 2018. Rodolfo Kusch's 'Estar' as seen as from the systemic perspective of Humberto Maturana as a way of 'Corazonar' coexistence. Australian Journal of Indigenous Education 48: 64-72.

Kusch R. -

2008. La negación en el pensamiento popular, Buenos Aires: Las Cuarenta. 2010. Indigenous and Popular Thinking in America, Durham: Duke University Press.

Lenkensdorf C. 2008. Aprender a escuchar. Enseñanzas maya-tojolabales, México D.F.: Plaza \& Valdés.

López I. 2014. Una genealogía: para pensar la expresión musical desde América Latina. In: Palermo Z (ed) Arte y estética en la encrucijada descolonial. Buenos Aires: Ediciones del siglo, 17-36. 
Maldonado-Torres N. 2016. Outline of Ten Theses on Coloniality and Decoloniality. Available at: https://fondation-frantzfanon.com/outline-of-ten-theses-on-colonialityand-decoloniality/.

Mignolo W. -

1992. La colonización del lenguaje y de la memoria: complicidades de la letra, el

libro y la historia. In: Zavala I (ed) Discursos sobre la 'invención' de América.

Amsterdam: Rodopi.

1995. The Darker Side of the Renaissance. Literacy, Territoriality, \& Colonization., Ann Arbor: The University of Michigan Press.

2002. The Enduring Enchantment: Or the Epistemic Privilege of Modernity and Where to Go from Here. Atlantic Quarterly 101: 927-954.

2010.. Estéticas decoloniales: sentir-pensar-hacer. Abya Yala / La Gran Comarca.

Bogotá.

2010b. Introduction. In: Kusch R (ed) Indigenous and Popular Thinking in América.

Durham: Duke University Press.

2011. Cosmopolitan Localism: A Decolonial Shifting of the Kantian's Legacies.

Localities 1: 11-45.

Monsalve F. 2013. Homeostasis: un continuo movimiento de adaptación, Santiago: Grijalbo.

Ong W. 1982. Orality and Literacy. The Technologizing of the World, London: Methuen.

Ortiz F. 1995. Cuban Counterpoint: Tobacco and Sugar, Durham: Duke University Press.

Pérez JTJ. 2013. El hedor de América. Reflexiones interdisciplinarias a 50 años de la América profunda de Rodolfo Kusch. EDUNTREF, Centro Cultural de la Cooperación Floreal Gorini.

Ponce D. 2008. Prueba de sonido: primeras historias del rock en Chile (1956-1984), Santiago: Ediciones B.

Pujol S. 2005. Rock y dictadura: crónica de una generación (1976-1983), Buenos Aires: Emecé.

Quijano A. 2000. Coloniality of Power, Eurocentrism, and Latin America. Nepantla: Views from South 1: 533-580.

Salas F. 2003. La primavera terrestre. Cartografías del rock chileno y la Nueva Canción chilena, Santiago: Cuerto Propio.

Sarmiento DF. 1845. Facundo: Civilización y Barbarie, Santiago: El Progreso.

Stock F. 2014. La vida mágica de Los Jaivas: Los caminos que se abren, Santiago: RIL Editores.

Varela HMF. 2002. El árbol del conocimiento, Santiago: Editorial Universitaria.

Vázquez R. 2012. Towards a Decolonial Critique of Modernity. Buen Vivir, Relationality and the Task of Listening. In: Fornet-Betancourt R (ed) Capital, Poverty, Development, Denktraditionen im Dialog: Studien zur Befreiung und interkulturalität. Aachen: Wissenschaftsverlag Mainz, 241-252.

Vázquez WMR. 2013. Decolonial AestheSis: Colonial Wounds/Decolonial Healings. Social Text Periscope (Web Publication).

Verden-Zoller HMG. 2003. Amor y juego. Fundamentos olvidados de lo humano. Desde el Patriarcado a la Democracia, Santiago: J.C. Saez.

Walsh C. 2018. The decolonial for: resurgences, shifts and movements. On Decoloniality: Concepts, Analytics, Praxis. Durham: Duke University Press, 28-45. 
Wynter S. 2003. Unsettling the Coloniality of Being/Power/Truth/Freedom: Towards the Human. After Man, Its Overrepresentation - An Argument. The New Centennial Review 3: 257-339.

\section{Discography}

Los Jaivas. -

El Volantín. Chile: RCA, 1971.

La Ventana. Chile: IRT, 1973. 